\title{
Kajian Kualitas Air tanah dan Sungai Pada Kawasan Rawan Banjir di Kabupaten Serang Kaitannya dengan Penyediaan Air Bersih
}

\section{Groundwater and River Water Quality Assessment in Serang District Flood Area Related to Providing Clean Water Supply}

\author{
HERU SRI NARYANTO, PRIHARTANTO, DELIYANTI GANESHA \\ Pusat Teknologi Reduksi Risiko Bencana, Kedeputian TPSA - Badan Pengkajian dan Penerapan Teknologi, \\ Gedung Geostech, Lantai 1, Kompleks Puspiptek Serpong, Tangerang Selatan \\ Email: heru.naryanto@bppt.go.id
}

\begin{abstract}
Serang District is the one of a flood-prone area, about 20 subdistricts were affected by the flood in Serang District. Problems of clean water necessity occurred in the flood area, especially water quality both surface water and groundwater. To know the condition of clean water in Serang District, it is necessary to study the quality of water both surface water and groundwater in the flood prone areas. The study was conducted with water sampling and in-situ water quality measurements at 28 open-pit points used by communities and river bodies in potential flood in 2012-2015. In-situ physical water quality measurements are performed during sampling of well water and river water using multiparameter quality checker equipment. Water quality parameters to be measured in-situ are: total dissolved solids (TDS) and turbidity. Laboratory tests of water samples were performed for suspended solid (TSS), Amonium $\left(\mathrm{NH}_{3}-\mathrm{N}\right)$, Iron ( $\left.\mathrm{Fe}\right)$, Manganese $(\mathrm{Mn})$ and total hardness parameters. The standard method of water quality analysis of these parameters is carried out using Indonesian National Standard SNI 06-6989.3-2004 water and wastewater. Turbidity tends to increase towards the downstream of the river indicating additional sediment material is transported downstream. The high total suspended solids in the river, especially in Kragilan due to the impact of waste from high domestic, commercial, and industrial activities in the area. Generally, groundwater and surface water in the flood areas at the study sites still largely indicate that quality is still feasible for consumption by the community, except for high Fe and $\mathrm{Mn}$ content and $\mathrm{NH}_{3} \mathrm{~N}$ in some wells due to the influence of surface water entering groundwater.
\end{abstract}

Keywords: Serang district, water quality, flood areas, water supply

\begin{abstract}
ABSTRAK
Kabupaten Serang termasuk wilayah yang rawan banjir, dari 29 kecamatan yang ada sekitar 20 kecamatan pernah terkena dampak banjir. Permasalahan kebutuhan air bersih terjadi pada kawasan banjir tersebut, terutama kualitas air baik air permukaan maupun air tanah. Untuk mengetahui secara rinci kondisi air bersih di kabupaten Serang, maka perlu dilakukan kajian kualitas air baik air permukaan maupun airtanah pada kawasan rawan banjir tersebut. Kajian dilakukan dengan pengambilan sampel air dan pengukuran in-situ kualitas air pada 28 titik sumur terbuka yang digunakan oleh masyarakat dan badan air sungai pada wilayah potensial genangan banjir tahun 2012-2015. Pengukuran kualitas air fisik secara in-situ dilakukan pada saat pengambilan sampel air sumur dan air sungai dengan menggunakan peralatan multiparameter quality checker, adalah: zat padat terlarut (total dissolved solids/TDS) dan turbiditas/kekeruhan. Sedangkan pemeriksaan laboratorium terhadap sampel air dilakukan untuk parameter zat padat tersuspensi (total suspended solid/TSS), Amonia bebas $\mathrm{NH}_{3}-\mathrm{N}$ ), Besi ( $\mathrm{Fe})$, Mangan ( $\mathrm{Mn}$ ) dan kesadahan total. Metode standard analisis kualitas air terhadap parameterparameter tersebut dilaksanakan menggunakan Standard Nasional Indonesia SNI 06-6989.3-2004 air dan air limbah. Kekeruhan cenderung meningkat ke arah hilir sungai menunjukkan adanya tambahan material sedimen tertransport pada bagian hilir. Tingginya zat padat tersuspensi pada sungai khususnya di Kragilan akibat dampak limbah dari aktivitas domestik, komersial dan industri yang tinggi di daerah tersebut. Secara umum airtanah dan air permukaan pada daerah banjir di lokasi penelitian sebagian besar masih menunjukkan kualitas yang masih layak untuk dikonsumsi oleh masyarakat, kecuali kandungan $\mathrm{Fe}$ dan $\mathrm{Mn}$ yang tinggi serta $\mathrm{NH}_{3}-\mathrm{N}$ pada beberapa sumur penduduk akibat pengaruh air permukaan termasuk air banjir masuk ke dalam airtanah.
\end{abstract}

Kata kunci: Kabupaten Serang, kualitas air, kawasan banjir, penyediaan air bersih 


\section{PENDAHULUAN}

\subsection{Latar Belakang}

Kejadian banjir berdampak terhadap perubahan kualitas air permukaan maupun air tanah. Penelitian di Cezh Republik menunjukkan bahwa banjir mengakibatkan dampak yang signifikan terhadap kualitas air $^{(1)}$. Pada tahun 2012 banjir yang terjadi di Beijing juga berdampak terhadap kualitas air minum $^{(2)}$. Hasil penelitian di Sungai Muar, Malaysia menunjukkan bahwa pada saat terjadi banjir diperoleh korelasi kekuatan yang lebih tinggi antara water quality index (WQI) dengan parameter kualitas air sungai pada periode sebelum dan selama gelombang pertama peristiwa banjir ${ }^{(3)}$.

Sungai-sungai utama di Kabupaten Serang yang sering mengalami banjir adalah Sungai Ciujung dan Sungai Cidurian. Banjir yang terjadi di Sungai Ciujung dipengaruhi oleh kondisi tutupan lahan pada DAS bagian hulunya. Kondisi tutupan lahan akan menentukan besarnya limpasan (runoff) yang terjadi $^{(4)}$.

Debit aliran sungai rata-rata tahunan pada periode 2004-2011 meningkat sebesar 15,2\% dibandingkan dengan periode 1999-2003. Hal ini menyebabkan terjadinya penurunan kualitas lingkungan pada DAS Ciujung yang berdampak terhadap kondisi Sungai Ciujung. Lahan yang potensial kritis di DAS Ciujung sebesar $56,5 \%$ dan $8,3 \%$ merupakan lahan kritis, sehingga fungsi hidrologisnya menurun yang berpotensi terjadi banjir di musim penghujan ${ }^{(5)}$.

Hampir setiap tahun di DAS Cidurian hilir yang sebagian besar adalah lahan terbuka dan terbangun mengalami banjir akibat kawasan yang tidak mampu menampung air hujan yang melebihi kapasitas tampung dari Sungai Cidurian itu sendiri. Tingkat kerawanan banjir di DAS Cidurian dipengaruhi oleh parameter penggunaan lahan, kemiringan lereng, elevasi, jenis tanah, curah hujan dan kedekatan dengan sungai ${ }^{(6)}$.

Kejadian banjir di kedua sungai ini diduga berdampak terhadap perubahan kualitas air. Beberapa penelitian mengenai kualitas air di Sungai Ciujung telah banyak dilakukan terkait dengan pengendalian pencemaran ${ }^{(7)}$, peningkatan kualitas air ${ }^{(8)}$, strategi pengelolaan sungai ${ }^{(9)}$. Disamping itu telah dilakukan penelitian tentang analisis beban pencemaran dan kapasitas asimilasi Sungai Cidurian $^{(10)}$. Tingginya nilai zat padatan tersuspensi di Kragilan pada hilir Sungai Ciujung pada musim kemarau 2013 kemungkinan akibat tingginya input zat padatan tersuspensi di Kragilan dari kegiatankegiatan domestik, perkotaan dan industri di wilayah ini ${ }^{(11)}$. Meskipun telah banyak penelitian mengenai kualitas air di kedua sungai tersebut, namun belum banyak penelitian yang membahas tentang pengaruh banjir terhadap perubahan kualitas air tanah maupun air permukaan di Kabupaten Serang.

Jumlah penduduk Kabupaten Serang terus meningkat setiap tahunnya. Pada tahun 2013 jumlah penduduk Kabupaten Serang sebanyak 1.450.894 jiwa, pada tahun 2015 jumlah tersebut telah bertambah menjadi sebanyak 1.463.064 jiwa (bertambah 12.170 jiwa $)^{(12)}$.

Kabupaten Serang merupakan salah satu wilayah di Provinsi Banten yang setiap tahunnya sering terkena banjir. Dari 29 (dua puluh sembilan) kecamatan yang ada, sekitar 20 (dua puluh) kecamatan yang terkena dampak banjir. Berdasarkan data dari BPBD Kabupaten Serang ${ }^{(13)}$, daerah yang paling rawan terkena banjir adalah Kecamatan Kragilan, Cikeusal, Kibin, Tanara, Tirtayasa, Cikande, Pontang, Binuang, Kopo, Padarincang dan Kecamatan Carenang ${ }^{(13)}$. Banjir yang dialami di wilayah Kabupaten Serang, sebagian besar disebabkan oleh meluapnya air dari Sungai Ciujung dan Sungai Cidurian terutama pada saat intensitas curah hujan tinggi.

Salah satu permasalahan yang ditemui di wilayah potensi genangan banjir di Kabupaten Serang adalah masalah kualitas air. Sebagian besar kebutuhan air minum masyarakat Kabupaten Serang masih menggunakan air dalam kemasan dan sebagian kecil menggunakan air PDAM. Masyarakat pada umumnya menggunakan airtanah dan air sungai untuk kebutuhan mandi, cuci dan kakus (MCK) dan hanya sebagian kecil masyarakat yang menggunakannya untuk air minum. Kondisi sanitasi masyarakat Kabupaten Serang yang masih kurang baik diperkirakan akan berdampak pada kualitas airtanah maupun sungai terutama pada saat banjir. Cakupan air bersih dari PDAM Kabupaten Serang untuk kebutuhan domestik hanya sekitar $40 \%$ dari jumlah penduduk Kabupaten Serang dan Cilegon pada tahun 2020, sehingga sisanya masih memanfaatkan airtanah untuk kebutuhan sehari-hari ${ }^{(14,15)}$.

\subsection{Maksud dan Tujuan Penelitian}

Maksud dari penelitian ini adalah untuk mengetahui dampak banjir terhadap kualitas air permukaan dan air tanah di kawasan potensi genangan banjir di Kabupaten Serang. 
Adapun tujuannya adalah untuk mengetahui kualitas air permukaan dan air tanah di kawasan potensi banjir kaitannya untuk penyediaan air bersih masyarakat di sekitarnya.

\section{METODOLOGI}

\subsection{Waktu dan Tempat Penelitian}

Penelitian ini dilakukan pada Maret-Juli 2016, pada saat tidak terjadi banjir. Metode penelitian yang digunakan adalah studi kasus. Penelitian studi kasus adalah penelitian tentang status subjek penelitian yang berkenan dengan suatu fase spesifik atau khas dari keseluruhan personalitas ${ }^{(16,17)}$. Pemilihan tempat penelitian dilakukan secara purpossive, dengan alasan Kabupaten Serang termasuk salah satu wilayah yang berpotensi terjadi banjir, sementara suplai air bersih sangat dibutuhkan.

\subsection{Metodologi Pengumpulan Data}

Metodologi pengambilan data adalah secara primer dan sekunder. Data primer adalah data-data yang diambil secara langsung dari survei lapangan dengan pengambilan sampel. Data sekunder didapatkan dari referensi terkait.

Pengolahan data pada penelitian ini disajikan sebagai berikut ${ }^{(18)}$ :

a. Penyusunan Data

b. Klasifikasi Data

c. Pengolahan Data

Pengolahan data merupakan proses analisis data dengan menelaah seluruh data yang tersedia dari berbagai sumber yakni wawancara, observasi, dokumen serta data lainnya. Pengolahan data untuk pemetaan wilayah terdampak banjir Kabupaten Serang 2013, 2014 dan 2015 serta pemetaan lokasi titik sampel air pada wilayah rawan banjir dilakukan melalui Software ArcGIS 10.1 dengan Editor Tools.

d. Interpretasi Hasil Pengolahan Data

Peneliti menginterpretasikan hasil analisis untuk menarik suatu kesimpulan yang berisikan intisari dari seluruh rangkaian kegiatan penelitian dan membuat rekomendasinya.

\subsection{Metodologi Analisis Kualitas Air}

Pada penelitian ini, sampel fisik air sebanyak 28 sampel ditentukan berdasarkan lokasi desa-desa terdampak banjir pada tahun 2013-2015 menurut BPBD Kabupaten Serang serta adanya ketersediaan aksesibilitas jalan sehingga titik sampel dapat diambil. Sampel air diambil pada sungai dan sumur gali atau jumblengan untuk istilah lokalnya. Sampel sungai diambil sebanyak 9 sampel pada Sungai Ciujung, Sungai Cidurian dan Sungai Cidanau. Sedangkan sampel sumur gali diambil sebanyak 19 sampel yang tersebar merata di wilayah terdampak banjir. Setelah 28 sampel tersebut diambil dan diukur parameter fisiknya, maka dilakukan uji laboratorium untuk dianalisis sifat fisik dan sifat biologi air tersebut sehingga dapat teridentifikasi kualitas airnya. Metodologi dan tahapan analisis kualitas air diperlihatkan pada Gambar 1.

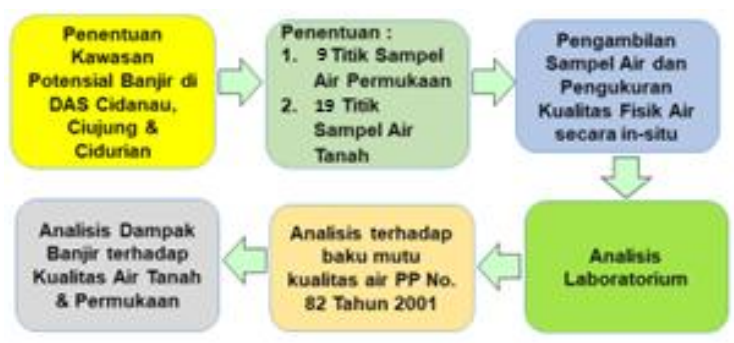

Gambar 1. Metode dan tahapan analisis kualitas air permukaan dan airtanah

Kualitas air didapatkan dengan mengambil sampel dan melakukan pengujian di laboratorium secara kimia dan biologi. Hasil pengujian laboratorium dibandingkan dengan baku mutu sebagai berikut:

- Baku mutu kualitas air menurut Peraturan Pemerintah No. 82 Tahun 2001 tentang Pengelolaan Kualitas Air dan Pengendalian Pencemaran Air ${ }^{(19)}$.

- Klasifikasi mutu air kelas satu, yaitu air yang peruntukannya dapat digunakan untuk air baku air minum, dan atau peruntukan lain yang mempersyaratkan mutu air yang sama dengan kegunaan tersebut

Metode standard dalam pengambilan dan analisis sampel kualitas air adalah:

a. Metode Standard Pengambilan Sampel Kualitas Air.

Pemeriksaan kualitas air dilakukan segera setelah pengambilan contoh. Apabila pemeriksaan air tidak dapat dilakukan segera setelah pengambilan contoh maka cara yang terbaik adalah dengan mendinginkan contoh pada suhu $4^{\circ} \mathrm{C}$. Pengawetan contoh dengan penambahan asam sampai $\mathrm{pH}$ lebih kecil atau sama dengan 2, untuk pengawetan logam terlarut dan logam total sehingga pemeriksaannya dapat ditunda selama beberapa minggu. 
b. Metode Standard Pengukuran Kualitas Air Secara In-situ.

Disamping pengambilan sampel air sumur dan air sungai, dilakukan pula pengukuran kualitas air fisik secara in-situ dengan menggunakan peralatan multiparameter quality checker. Parameter-parameter kualitas air yang akan diukur secara in-situ dengan peralatan water quality checker adalah: zat padat terlarut (total dissolved solids/TDS), turbiditas/kekeruhan dan salinitas.

c. Metode Standard Analisis Laboratorium. Analisis kualitas air terhadap 28 sampel yang telah diambil di lapangan dilakukan untuk pengujian parameter Besi $(\mathrm{Fe})$, Mangan (Mn), (Cd), Amonium (N-NH$)_{3}$, Salinitas (PSU), Kesadahan Total. Sedangkan data TSS dan TDS pada tahun 2014 menggunakan data hasil pemeriksaan sampel yang dilakukan oleh BPLHD Provinsi Banten. Metode standard analisis kualitas air terhadap parameterparameter tersebut dilaksanakan menggunakan Standard Nasional Indonesia SNI 06-6989.3-2004 air dan air limbah ${ }^{(20)}$.

\subsection{Pengambilan Sampel Lapangan}

Sebanyak 28 sampel air diambil berdasarkan lokasi desa-desa terdampak banjir pada tahun 2013-2015 menurut data BPBD Kabupaten Serang. Sampel air diambil pada sungai dan sumur gali penduduk. Sampel sungai diambil sebanyak 9 sampel di Sungai Ciujung, Sungai Cidurian dan Sungai Cidanau, sedangkan pada sumur gali diambil sebanyak 19 sampel yang tersebar merata di wilayah terdampak banjir. Setelah 28 sampel tersebut diambil dan diukur parameter fisiknya secara in-situ, maka dilakukan uji laboratorium untuk parameter fisik dan biologi air tersebut sehingga dapat teridentifikasi kualitas airnya.

Titik-titik pengambilan sampel dan pengukuran in-situ berjumlah 28 titik yang terdiri dari sumur terbuka yang digunakan masyarakat dan badan air sungai pada wilayah potensial genangan banjir. Secara rinci sebaran jumlah masing-masing titik sampel adalah sebagai berikut:

a. Sampel air sungai: Sungai Ciujung, Sungai Cidurian dan Sungai Cidanau sebanyak 9 sampel

b. Sampel airtanah: sumur terbuka di area potensial genangan banjir sebanyak 19 sampel

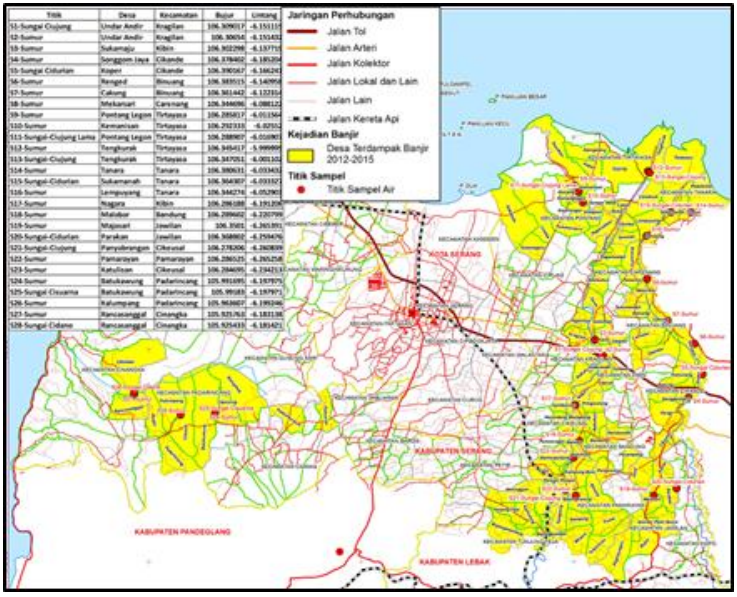

Gambar 2. Lokasi pengambilan sampel air pada kawasan rawan banjir di Kabupaten Serang tahun 2013, 2014 dan 2015
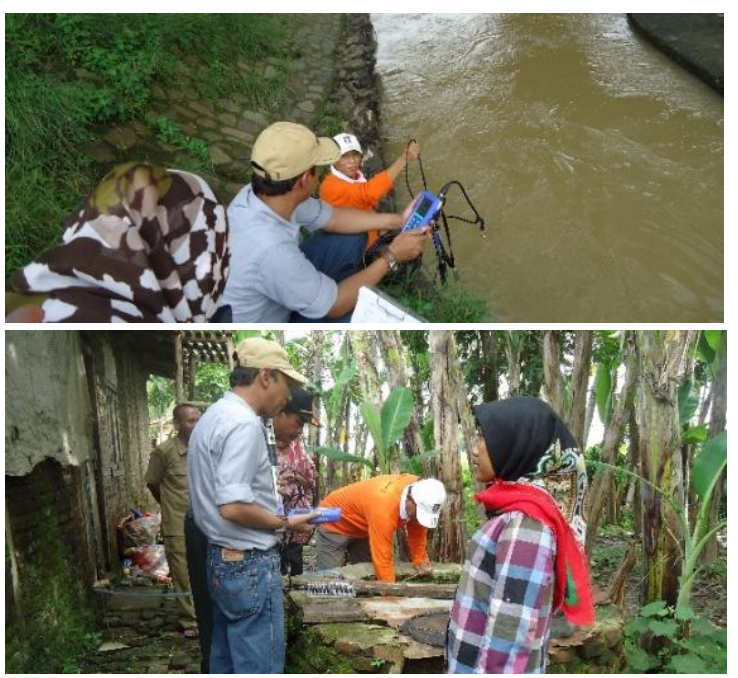

Gambar 3. Pengambilan sampel air Sungai Ciujung dan airtanah dari sumur penduduk

\section{DATA DAN PEMBAHASAN}

\subsection{Kondisi Hidrologi Kabupaten Serang}

Kondisi airtanah di Kabupaten Serang umumnya dangkal, yaitu antara 0,5 - 7 meter dari permukaan tanah dan cenderung mengikuti pola permukaan tanah. Badan air yang terdapat di Kabupaten Serang adalah 5 (lima) buah sungai yang bermuara di Selat Sunda dan Laut Jawa serta sebuah danau. Sedangkan sumber mata air antara lain mata air Sukacai dengan debit $\pm 240 \mathrm{~L} /$ detik dan mata air Cibanten dengan debit \pm 750 L/detik. Di sebelah timur wilayah Kabupaten Serang umumnya tidak terdapat mata air, sedangkan di sebelah barat memiliki potensi mata air dari rendah sampai dengan sedang.

Airtanah di Kabupaten Serang tersedia dalam jumlah yang relatif cukup. Pada 
umumnya airtanah dangkal di daerah dataran mempunyai kedalaman antara $0,5 \mathrm{~m}-3,0 \mathrm{~m}$, sedangkan di daerah perbukitan kedalamannya $\pm 15 \mathrm{~m}$. Penyebaran sumber airtanah ini terdapat di bagian tenggara di mana airtanah membentuk mata air di lereng Gunung Karang. Selain airtanah, Kabupaten Serang juga memiliki beberapa mata air dengan debit yang cukup besar ( $>100$ liter/detik). Mata air ini jika diolah dengan baik dapat memenuhi kebutuhan air bersih di Kabupaten Serang.

Kebutuhan air di Kabupaten Serang untuk 4 sektor kegiatan antara lain, industri, perikanan, PDAM, dan irigasi di Kabupaten Serang sebesar 75,5615 m³/det. Dibandingkan dengan potensi sumber air yang ada di Kabupaten Serang, jumlah kebutuhan tersebut bisa dipenuhi oleh sumber air yang ada ${ }^{(21)}$.

\subsection{Kawasan Rawan Banjir Kabupaten Serang}

Salah satu wilayah yang langganan terkena banjir adalah Kabupaten Serang, khususnya yang berada di sepanjang aliran Sungai Ciujung dan Sungai Cidurian. Pada Tahun 2013 terdapat 20 Kecamatan dari 29 kecamatan di Kabupaten Serang yang rawan banjir dengan jumlah area tergenang banjir $437,224 \mathrm{Km}^{2}$. Daerah rawan banjir yang dialiri Sungai Ciujung dan Sungai Cikande adalah kecamatan-kecamatan Bandung, Binuang, Carenang, Cikande, Cikeusal, Cinangka, Ciomas, Ciruas, Jawilan, Kibin, Kopo, Kragilan, Kramatwatu, Padarincang, Pamarayan, Petir, Pontang, Tanara, Tirtayasa, dan Tunjung Teja (Tabel 1).

Tabel 1. Data tabel daerah genangan banjir di Kabupaten Serang tahun $2013^{(13)}$

\begin{tabular}{c|l|c|r}
\hline No & Kecamatan & $\begin{array}{c}\text { Jumlah } \\
\text { Desa/ Kel. }\end{array}$ & $\begin{array}{c}\text { Luas Area } \\
\text { Genangan } \\
\left(\mathrm{Km}^{2}\right)\end{array}$ \\
\hline & Bandung & 8 & 25.252 \\
\hline 2. & Binuang & 6 & 26.565 \\
\hline 3. & Carenang & 6 & 21.845 \\
\hline 4. & Cikande & 6 & 24.543 \\
\hline 5. & Cikeusal & 7 & 24.102 \\
\hline 6. & Cinangka & 1 & 7.923 \\
\hline 7. & Ciomas & 1 & 2.711 \\
\hline 8. & Ciruas & 6 & 15.433 \\
\hline 9. & Jawilan & 5 & 20.304 \\
\hline 10. & Kibin & 6 & 17.756 \\
\hline 11. & Kopo & 7 & 27.427 \\
\hline 12. & Kragilan & 4 & 13.718 \\
\hline 13. & Kramatwatu & 6 & 27.962 \\
\hline 14. & Padarincang & 10 & 73.873 \\
\hline & & &
\end{tabular}

\begin{tabular}{r|l|r|r}
\hline 15. & Pamarayan & 6 & 25.787 \\
\hline 16 & Petir & 2 & 5.738 \\
\hline 17. & Pontang & 1 & 12.177 \\
\hline 18 & Tanara & 8 & 43.179 \\
\hline 19. & Tirtayasa & 1 & 7.702 \\
\hline 20. & $\begin{array}{l}\text { Tunjung } \\
\text { Teja }\end{array}$ & 3 & 13.227 \\
\hline \multicolumn{2}{l|}{ Jumlah } & 100 & 437.224
\end{tabular}

Pada tahun 2014, terdapat 12 dari 28 kecamatan di Kabupaten Serang terkena banjir. Daerah banjir yang dialiri Sungai Ciujung yakni Kecamatan Pamarayan, Cikeusal, Bandung, Kibin, Carenang, Cikande, Kragilan, Pontang, Tanahara, dan Kecamatan Tirtayasa. Sedangkan yang dialiri Sungai Cidurian, yakni Kecamatan Kopo dan Kecamatan Jawilan. Sedangkan tahun 2015, kawasan rawan bencana banjir di Kabupaten Serang yaitu Kecamatan Kragilan, Cikeusal, Kibin, Tanara, Tirtayasa, Cikande dan Kecamatan Carenang. terdapat dua aliran yang biasanya mengalami banjir apabila hujan di daerah selatan tinggi yaitu Sungai Ciujung dan Sungai Ciuyah ${ }^{(13,22)}$.

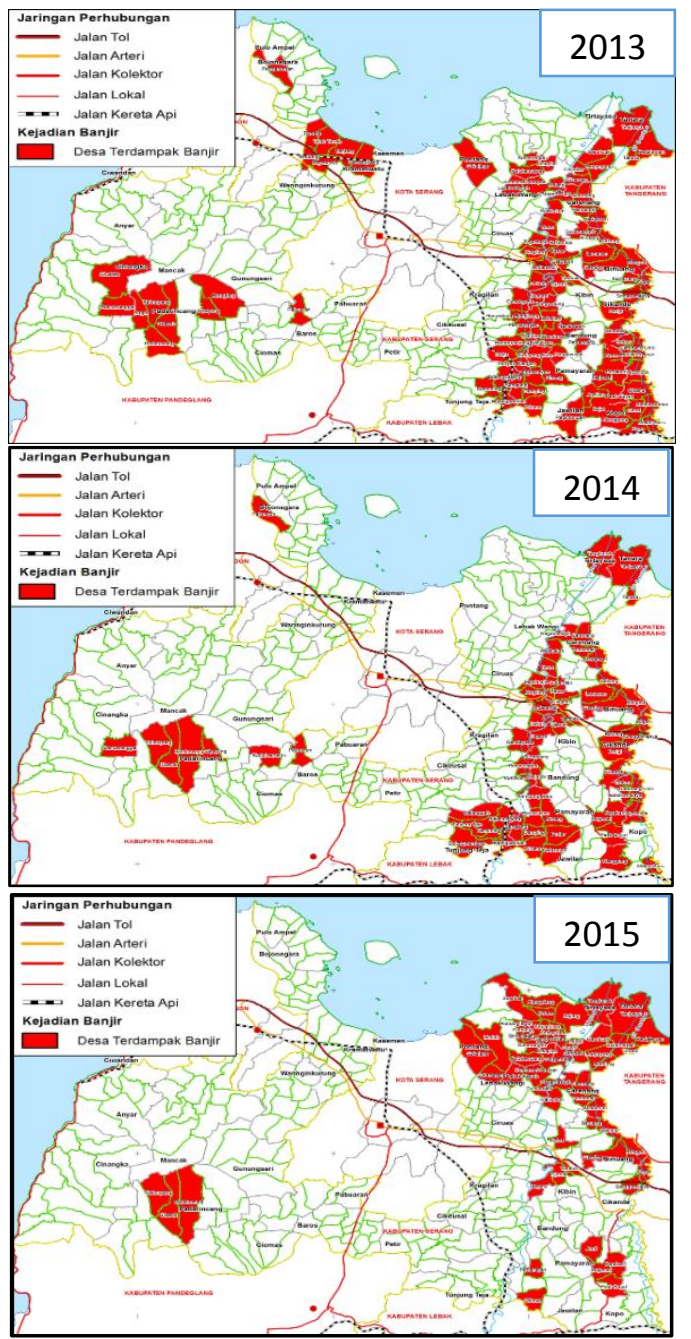


Gambar 4. Lokasi terdampak bencana banjir di Kabupaten Serang tahun 2013, 2014 dan $2015^{(13)}$

\subsection{Analisis Kualitas Airtanah dan Air Sungai pada Kawasan Rawan Banjir}

\subsubsection{Zat Padat Terlarut, Zat Padat Tersuspensi dan Turbiditas}

Bencana banjir yang sering terjadi di area potensial banjir di DAS Ciujung, Cidurian dan Cidanau diduga akan meningkatkan kekeruhan air sungai yang mempunyai korelasi kualitatif pada peningkatan total zat padatan tersuspensi (total suspended solids/TSS) pada aliran sungai-sungai tersebut. Penelitian di Cezh Republic menunjukkan bahwa pada kecepatan aliran rendah mengakibatkan konsentrasi yang rendah dari padatan tersuspensi (penurunan $62 \%)$ dan logam ${ }^{(1)}$.

TSS adalah residu dari padatan total yang tertahan oleh saringan dengan ukuran partikel maksimal $2 \mu \mathrm{m}$ atau lebih besar dari ukuran partikel koloid ${ }^{(23)}$. TSS memberikan kontribusi terhadap kekeruhan air yang dapat membatasi penetrasi cahaya untuk fotosintesis dan visibilitas di perairan.

Hasil pemantauan kualitas air pada parameter zat padat terlarut (Total Dissoled Solids/TDS) dan zat pada tersuspensi (Total Suspended Solids/TSS) di Sungai Ciujung yang dilakukan BLHD Provinsi Banten pada musim kemarau tahun 2013 menunjukkan bahwa rentang TDS di sepanjang Sungai Ciujung berkisar antara 41 - $97 \mathrm{mg} / \mathrm{Liter}$. Sedangkan TSS berkisar antara 52 - 182 $\mathrm{mg} /$ Liter diperlihatkan pada Tabel 2.

Tabel 2. Pemantauan kualitas air Sungai Ciujung 22 Juli -16 Agustus $2013^{(9)}$

\begin{tabular}{clcc}
\hline No. & Lokasi & \multicolumn{2}{c}{ Parameter } \\
\cline { 3 - 4 } & $\begin{array}{c}\text { Zat Padat } \\
\text { Terlarut } \\
(\mathrm{mg} / \mathrm{L})\end{array}$ & $\begin{array}{c}\text { Zat Padat } \\
\text { Tersuspensi } \\
(\mathrm{mg} / \mathrm{L})\end{array}$ \\
\hline 1. & $\begin{array}{l}\text { Hulu } \\
\text { Cisalaraja }\end{array}$ & 97 & 182 \\
\hline 2. & Ciberang & 41 & 114 \\
\hline 3. & $\begin{array}{l}\text { Jembatan } \\
\text { Baru }\end{array}$ & 62 & 108 \\
\hline 4. & $\begin{array}{l}\text { Bendung } \\
\text { Pamarayan }\end{array}$ & 56 & 52 \\
\hline 5. & Kragilan & 56 & 232 \\
\hline 6. & Jong Jing & 73 & 61 \\
\hline
\end{tabular}

Dari Gambar 5 terlihat bahwa pada musim kemarau, Bendung Pamarayan akan menahan aliran dan menurunkan TSS pada aliran Sungai Ciujung karena terjadi perlambatan kecepatan aliran Sungai Ciujung. Pada musim kemarau 2013 terlihat bahwa terjadi penurunan TSS dari hulu Sungai Ciujung di Cisalaraja hingga Bendung Pamarayan yang menunjukkan adanya dugaan terjadinya sedimentasi sepanjang penggal Cisalaraja Bendung Pamarayan pada musim kemarau.

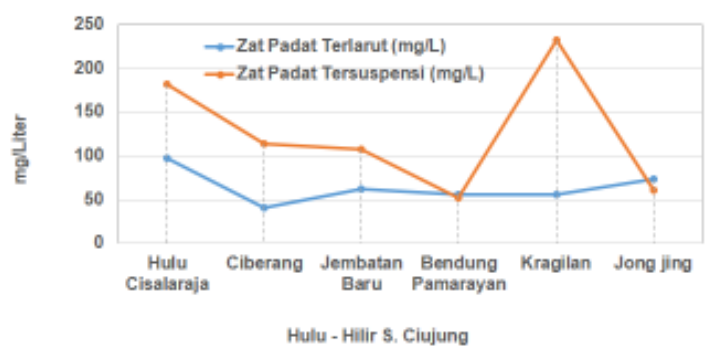

Gambar 5. Zat padat terlarut dan zat padat tersuspensi sepanjang Sungai Ciujung

Belum dapat diketahui secara pasti penyebab tingginya nilai TSS di Kragilan pada tahun 2013, namun tingginya aktivitas domestik, komersial dan industri di Kragilan diduga menjadi salah satu penyebab tingginya input TSS di Kragilan dari kegiatan-kegiatan tersebut. Namun bila dibandingkan dari beban pencemar TSS di Kragilan diduga sumber utama TSS berasal dari sumber domestik dan industri. Hal ini berdasarkan hasil analisis tata guna lahan di sepanjang Sungai Ciujung paling banyak ditemukan permukiman dan industri di sekitar Kragilan

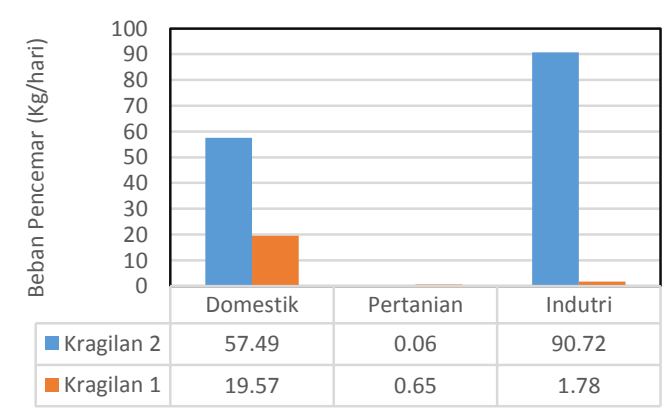

Gambar 6. Perbandingan beban pencemar TSS dari beberapa sumber di Kragilan $^{(24)}$

Apabila dibandingkan dengan hasil pengukuran Kekeruhan (turbiditas) secara insitu pada musim hujan 2016 terukur bahwa Kekeruhan Sungai Ciujung berkisar antara 136-231,9 mg/Liter sebagaimana diperlihatkan grafik berikut : 


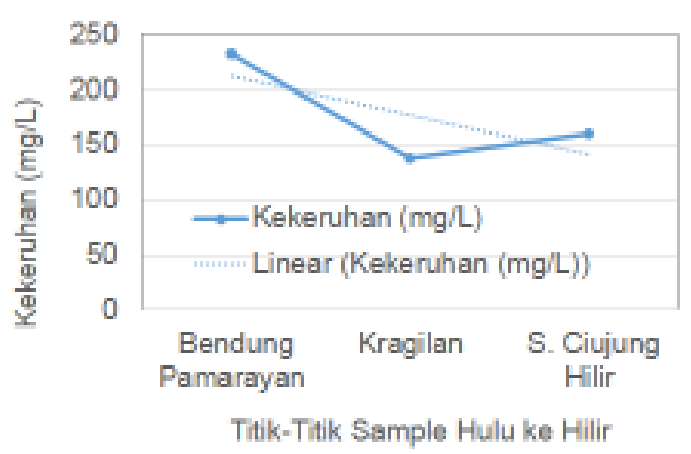

Gambar 7. Kekeruhan Sungai Ciujung huluhilir di Sungai Ciujung

Dari Gambar 7 dapat dijelaskan bahwa secara umum kekeruhan meningkat dari hulu ke hilir yang ditunjukkan dengan meningkatnya kekeruhan dari Kragilan ke arah Sungai Ciujung hilir. Meskipun tidak ada korelasi secara langsung antara TSS dan kekeruhan, namun dapat dijelaskan bahwa secara umum peningkatan TSS akan memperlihatkan peningkatan kekeruhan secara kualitatif terutama pada musim hujan.

TSS memberikan kontribusi untuk kekeruhan dengan membatasi penetrasi cahaya ke dalam air. Sehingga nilai kekeruhan tidak dapat dikonversi ke nilai TSS. Kekeruhan adalah kecenderungan ukuran sampel untuk menyebarkan cahaya. Sementara hamburan diproduksi oleh adanya partikel tersuspensi dalam sampel. Kekeruhan adalah murni sebuah sifat optik ${ }^{(25)}$.

Peningkatan kekeruhan ini kemungkinan besar diakibatkan oleh akumulasi TSS pada saat banjir terjadi yang terbawa oleh aliran permukaan menuju sungai dari hulu ke hilir.

Kekeruhan yang relatif tinggi di Bendung Pamarayan dibandingkan kekeruhan di hilir sungai disebabkan oleh lokasi pengukuran kekeruhan dilakukan tepat di atas atau sebelum Bendung Pamarayan. Pada lokasi tesebut terjadi akumulasi TSS dari hulu sungai yang terkumpul di Bendung Pamarayan. Hal ini menjelaskan mengapa nilai kekeruhan di Bendung Pamarayan relatif tinggi dibandingkan Kragilan dan Sungai Ciujung. Bila ketiga hasil pengukuran tersebut disandingkan timbul kesan seakan-akan mengalami penurunan kekeruhan.

Hasil pemantauan kualitas air pada parameter kekeruhan di Sungai Cidurian menunjukkan bahwa kekeruhan di hilir lebih tinggi daripada hulu. Bila ditinjau dari wilayah DAS Cidurian, penetapan hulu sungai Cidurian yang diambil sebagai titik sampel hulu pada dasarnya sudah masuk ke dalam wilayah tengah dari DAS Cidurian.
Tingginya kekeruhan di wilayah hilir sungai menunjukkan adanya dugaan transportasi sedimen ke arah hilir. Penurunan kekeruhan di wilayah tengah Sungai Cidurian menunjukkan adanya pengaruh peningkatan debit sungai yang salah satunya berasal dari inflow saluran drainage di tengah Sungai Cidurian. Penambahan debit aliran permukaan ke dalam Sungai Cidurian akan menyebabkan terjadinya pengenceran air sungai sehingga akan menurunkan kekeruhan sebagaimana diperlihatkan pada Gambar 8.

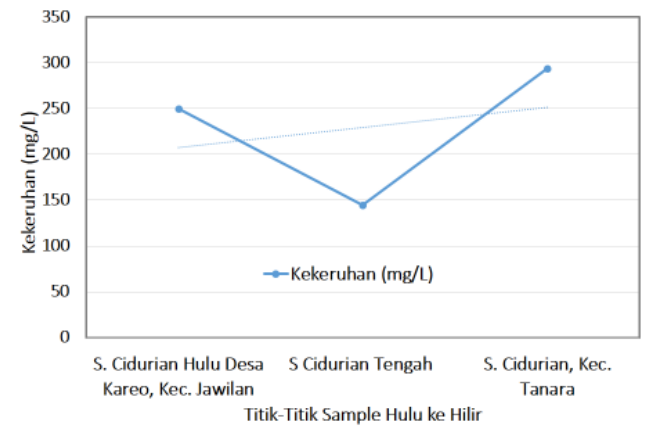

Gambar 8. Kekeruhan air arah hulu-hilir di Sungai Cidurian

Dengan gambaran seperti itu, dapat diduga pada saat terjadi banjir, maka transportasi sedimen dari hulu menuju hilir akan semakin meningkat bersamaan dengan meningkatnya debit sungai. Sedimen dapat berasal dari beberapa sumber domestik, industri maupun dari limpasan hujan dan erosi yang dapat terbawa melalui saluran drainage perkotaan, saluran irigasi atau terlimpas langsung melalui aliran permukaan langsung menuju sungai.

Hasil pemantauan kualitas air pada parameter kekeruhan di Sungai Cidanau dan beberapa sungai kecil di DAS Cidanau menunjukkan bahwa kekeruhan relatif rendah dibandingkan kekeruhan yang ada di Sungai Cidurian dan Sungai Ciujung. Hal ini menunjukkan bahwa tingkat erosi yang terjadi di DAS Cidanau lebih rendah dibandingkan dengan Sungai Ciujung dan Sungai Cidurian ${ }^{(26)}$. 


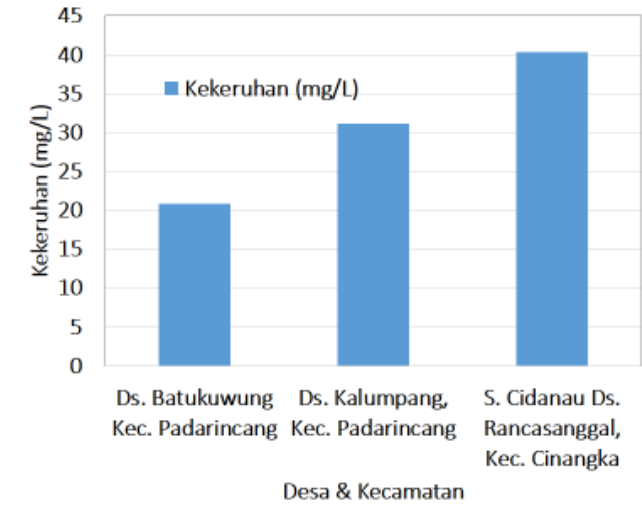

Gambar 9. Kekeruhan air arah hulu-hilir di Sungai Cidanau

\subsubsection{Amonia $\left(\mathrm{NH}_{3}-\mathrm{N}\right)$}

Kadar $\mathrm{N}$ dalam bentuk $\mathrm{NH}_{3}$ bebas dipakai juga sebagai indikator untuk menyatakan derajat polusi. Kadar $0,5 \mathrm{mg} / \mathrm{l}$ dalam bentuk $\mathrm{NH}_{3}$ bebas merupakan batas maksimum yang lazim dianggap sebagai batas untuk menyatakan bahan air itu tidak tercemar. Ikan masih dapat hidup pada air yang mengandung $\mathrm{N}$ sebesar $2 \mathrm{mg} / \mathrm{l}$. Batas letal akan tercapai pada kadar $5 \mathrm{mg} / \mathrm{l}$. Baku mutu $\mathrm{NH}_{3}$ bebas untuk air baku air minum menurut PP No. 82 tahun 2001 adalah sebesar $0,5 \mathrm{mg} / \mathrm{L}$ atau setara dengan $0,411 \mathrm{NH}_{3}-\mathrm{N}$ sedangkan dalam KepMenKes No. 907/MENKES/SK/VII/2002 baku mutu air minum ditetapkan $\mathrm{NH}_{3}$ bebas lebih longgar sebesar $1,5 \mathrm{mg} / \mathrm{L}^{(27)}$. Namun baku mutu $\mathrm{NH}_{3}$ bebas tidak ditetapkan dalam baku mutu air minum terbaru yaitu Permenkes No. 492/MENKES/PER/IV/2010.

Berdasarkan hasil analisis sampel air sumur dan air sungai diperoleh hasil bahwa konsentrasi $\mathrm{NH}_{3}-\mathrm{N}$ di beberapa titik sampel telah terdeteksi, hal ini menunjukkan kemungkinan adanya input bahan-bahan organik maupun anorganik yang berasal dari lingkungan.

Tingginya nilai $\mathrm{NH}_{3}-\mathrm{N}$ di beberapa sumur penduduk kemungkinan besar disebabkan oleh limpasan air permukaan yang membawa limbah organik maupun anorganik masuk ke dalam sumur penduduk yang tidak terlindungi terutama pada saat banjir. Ada beberapa sumber utama $\mathrm{NH}_{3}-\mathrm{N}$ yang dapat mencemari sumur penduduk yaitu limbah cair domestik ${ }^{(28)}$ dan penggunaan pupuk di lahan pertanian dan perkebunan $^{(29)}$. Dari Peta RBI BIG, diperoleh luas lahan pertanian dan perkebunan di Kecamatan Kragilan masing-masing seluas $2327,8 \mathrm{Ha}(52,2 \%)$ dan 692,14 Ha (15,5\%) dari luas Kec. Kragilan 4457,53 Ha. Dengan luas lahan pertanian dan perkebunan tersebut, maka penggunaan pupuk organik dan anorganik di lahan pertanian dan perkebunan bila terbawa aliran permukaan pada saat banjir patut diduga dapat membawa amonia yang dapat mencemari sumur yang tidak terlindungi di Kragilan. Kondisi fisik sumur gali di Desa Sentul, Kecamatan Kragilan dari 69 responden, terdapat $56(81,2 \%)$ sumur gali yang memiliki kondisi fisik tidak baik ${ }^{(30)}$. Untuk itu dibutuhkan perlindungan dinding sumur agar limpasan air hujan atau genangan banjir tidak dapat masuk ke dalam sumur.

Nilai $\mathrm{NH}_{3}-\mathrm{N}$ yang tinggi di Sungai Cidanau, Sungai Ciujung dan Sungai Cidurian kemungkinan besar karena adanya kontribusi penggunaan pupuk organik dan anorganik dari lahan pertania, saluran drainase yang membawa limbah cair organik maupun sampah yang masuk ke dalam sungai.

a. $\mathrm{NH}_{3}-\mathrm{N}$ di Hulu, Tengah dan Hilir Sungai Ciujung

Pada saat Sungai Ciujung memasuki wilayah Kabupaten Serang, nilai $\mathrm{NH}_{3}-\mathrm{N}$ telah melampaui mencapai 3,05 $\mathrm{mg} / \mathrm{L}$ yang berarti sudah input $\mathrm{NH}_{3}-\mathrm{N}$ di wilayah hulu Sungai Ciujung. Kontribusi $\mathrm{NH}_{3}-\mathrm{N}$ telah terjadi mulai dari hulu (Bendung Pamarayan) dan menurun hingga hilir. Nilai $\mathrm{NH}_{3}-\mathrm{N}$ yang menurun ke arah hilir menunjukkan telah terjadi dekomposisi organik pada senyawa $\mathrm{NH}_{3}-\mathrm{N}$. Meskipun telah terjadi dekomposisi organik sepanjang sungai tetapi tidak mampu menurunkan konsentrasi $\mathrm{NH}_{3}-\mathrm{N}$ hingga di bawah baku mutu. Sumber utama pencemar bahan organik $\mathrm{NH}_{3}-\mathrm{N}$ berasal dari penggunaan pupuk organik dan anorganik di lahan pertanian dan perkebunan, limbah domestik maupun industri. Untuk menurunkan $\mathrm{NH}_{3}-\mathrm{N}$ perlu dilakukan pengolahan limbah rumah tangga maupun industri yang menghasilkan $\mathrm{NH}_{3}-\mathrm{N}$. Penggunaan tangki septik rumah tangga maupun komunal dapat menjadi alternatif penurunan $\mathrm{NH}_{3}-\mathrm{N}$ dari sumber rumah tangga. Dalam kondisi banjir diperkirakan kadar $\mathrm{NH}_{3}-\mathrm{N}$ dapat meningkat akibat adanya inflow dari saluran drainase perkotaan yang kemungkinan membawa limbah organik. Dalam kondisi banjir diperkirakan kadar $\mathrm{NH}_{3}-\mathrm{N}$ dapat meningkat seiring dengan peningkatan inflow dari limpasan air hujan, hal ini dapat membawa bahan $\mathrm{NH}_{3}-\mathrm{N}$ dari penggunaan pupuk organik dan anorganik dari lahan pertanian dan perkebunan.

Hasil analisis simulasi kualitas air Sungai Ciujung menggunakan model WASP (Water Quality Analysis Simulation Program $)^{(31)}$ menunjukkan bahwa peningkatan debit di lokasi Sukamaju dan Kragilan pada musim hujan akan 
meningkatkan konsentrasi amonia. Pada debit minimum konsentrasi $\mathrm{NH}_{3}-\mathrm{N}$ berkisar antara $0,01-1,42 \mathrm{mg} / \mathrm{L}$, dengan rata-rata sebesar $0,18 \mathrm{mg} / \mathrm{L}$. Pada debit maksimum meningkat menjadi berkisar antara 0,02 $1,62 \mathrm{mg} / \mathrm{L}$ dengan rata-rata $0,41 \mathrm{mg} / \mathrm{L}$. Hal ini menjelaskan bahwa peningkatan $\mathrm{NH}_{3}-\mathrm{N}$ di Kragilan terjadinya akibat peningkatan inflow aliran permukaan pada saat banjir atau debit maksimum.

b. Amonia di Hulu, Tengah dan Hilir Sungai Cidurian

Sebagaimana Sungai Ciujung, ketika Sungai Cidurian memasuki wilayah Kabupaten Serang, konsentrasi $\mathrm{NH}_{3}-\mathrm{N}$ telah mencapai $2,34 \mathrm{mg} / \mathrm{L}$ yang menunjukkan sudah adanya input bahan organik sejak dari wilayah hulu Sungai Cidurian sejak dari hulu. Di Sungai Cidurian Tengah menurun menjadi $1,87 \mathrm{mg} / \mathrm{L}$. Konsentrasi $\mathrm{NH}_{3}-\mathrm{N}$ menurun hingga 1,07 $\mathrm{mg} / \mathrm{L}$ di hilir Sungai Cidurian. Penyebab penurunan $\mathrm{NH}_{3}-\mathrm{N}$ dari hulu hingga hilir Sungai Cidurian belum dapat dijelaskan dalam penelitian ini, dugaan terhadap kemungkinan pengenceran $\mathrm{NH}_{3}-\mathrm{N}$ akibat peningkatan debit banjir perlu dianalisis lebih lanjut keterkaitannya antara konsentrasi $\mathrm{NH}_{3}-\mathrm{N}$ dengan debit Sungai Cidurian.

c. Amonia di Sungai Cidanau.

Nilai $\mathrm{NH}_{3}-\mathrm{N}$ di Sungai Cidanau hanya diambil pada satu titik di Desa Rancasanggal dengan nilai $\mathrm{NH}_{3}-\mathrm{N}$ hingga mencapai $1,78 \mathrm{mg} / \mathrm{L}$. Nilai $\mathrm{NH}_{3}-\mathrm{N}$ ini menunjukkan adanya input bahan organik dan anorganik di Sungai Cidanau. Dua sampel lain yang diambil di DAS Cidanau juga menunjukkan kondisi yang sama pada badan air.

\subsubsection{Parameter Fe dan Mn}

Kandungan Fe dan Mn dari ke 28 Sampel air sumur maupun air sungai secara umum melampaui baku mutu Golongan I, hal ini berkaitan dengan kondisi geologi di Kabupaten Serang yang banyak mengadung Besi dan Mangan pada air tanahnya. Kondisi ini tidak terkait dengan kejadian banjir secara langsung terutama terhadap konsentrasi $\mathrm{Fe}$ dan $\mathrm{Mn}$ pada airtanah. Batas baku kualitas air baku air minum untuk parameter $\mathrm{Fe}$ dan $\mathrm{Mn}$, masingmasing adalah $0,3 \mathrm{mg} / \mathrm{L}$ dan $0,1 \mathrm{mg} / \mathrm{L}$.

Dalam kondisi banjir agar airtanah tetap dapat dikonsumsi sebagai air minum, maka dibutuhkan pengolahan air untuk menurunkan Fe dan Mn. Teknologi untuk menghilangan besi dan mangan bisa dilakukan dengan banyak cara, yang antara lain adalah: dengan cara oksidasi (oksidasi dengan udara/aerasi, oksidasi dengan khlorine/khlorinasi, oksidasi dengan kalium permangganat), dengan cara koagulasi (penambahan bahan koagulan, dengan cara elektrolitik), dengan cara pertukaran ion (dengan siklus untuk $\mathrm{Na}$, menggunakan zeolite, menggunakan resin sintetis, dengan siklus hidrogen), dengan filtrasi kontak (media filter yang mengandung $\mathrm{MNO}_{2}$, dengan mangan zeolite), proses soda lime, dengan bakteri besi serta dengan filtrasi dua tahap ${ }^{(32)}$.

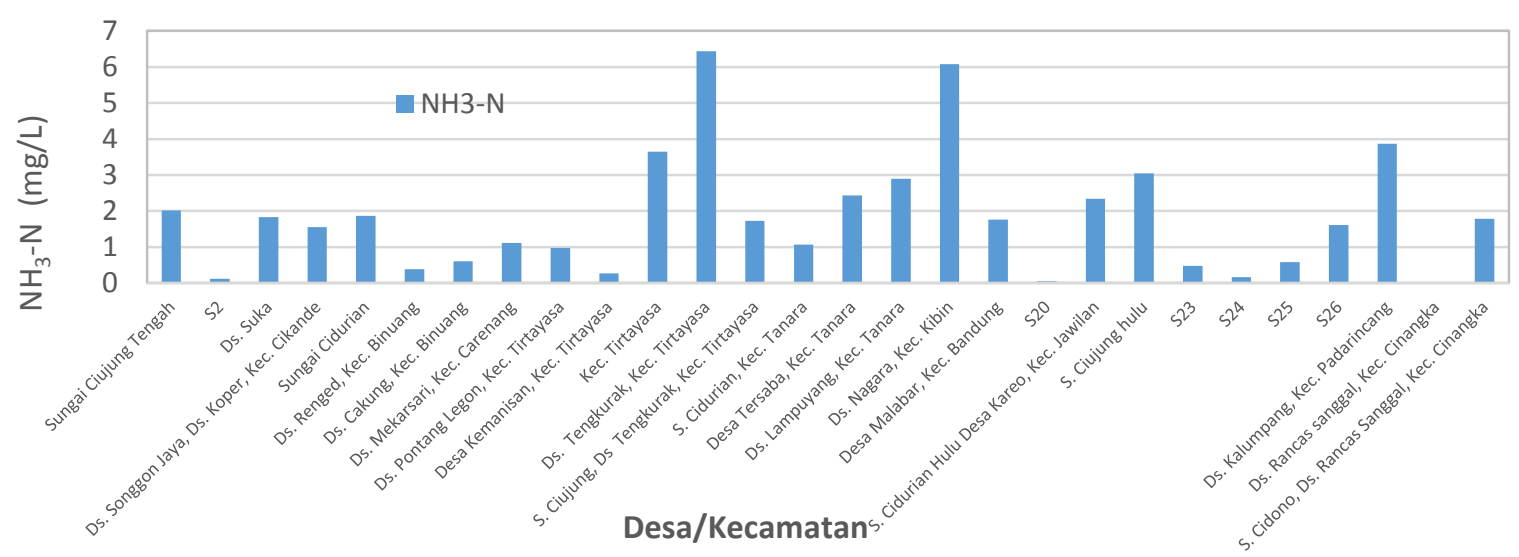

Gambar 10. Nilai $\mathrm{NH}_{3}-\mathrm{N}$ pada 28 sampel air

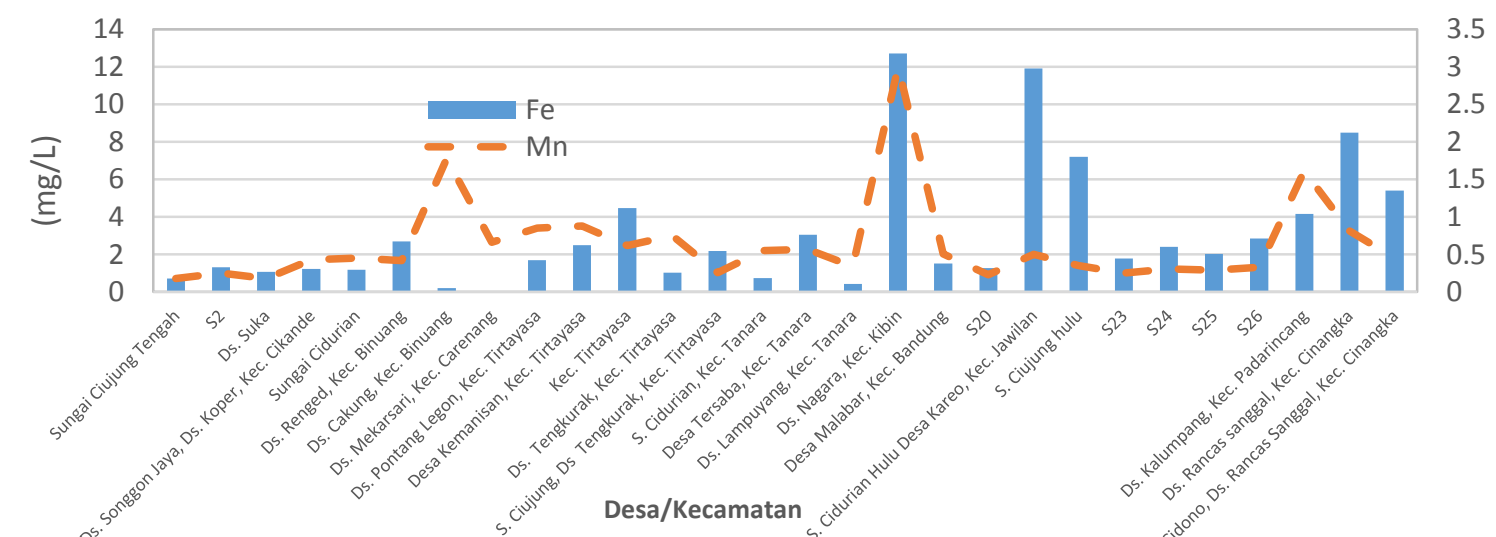


Gambar 11. Konsentrasi Fe dan Mn pada 28 sampel air sumur dan sungai

\subsubsection{Kesadahan Air}

Hasil pengukuran terhadap 28 sampel air yang diperiksa, hanya 2 sampel yang menunjukkan kesadahan di atas $300 \mathrm{mg} / \mathrm{L}$, yaitu Desa Pontang Legon dan Desa Kemanisan, Kecamatan Tirtayasa. Tingkat kesadahan sekitar $200 \mathrm{mg} / \mathrm{L}$ terdapat di Desa Tengkurak, Kecamatan Tirtayasa dan Desa Lampuyang, Kec. Tanara. Tingkat kesadahan untuk sampel lainnya relatif kecil, yaitu di bawah $200 \mathrm{mg} / \mathrm{L}$.

Berdasarkan baku mutu yang ditetapkan oleh Kementerian Kesehatan No. 492/MENKES/PER/IV/2010, baku mutu maksimum kesadahan total sebesar 500 $\mathrm{mg} / \mathrm{L}^{(33)}$. Berdasarkan hasil pengukuran kesadahan pada ke-28 sampel air yang diperiksa menunjukkan bahwa keseluruhan sampel masih mempunyai harga di bawah 500 $\mathrm{mg} / \mathrm{L}$, sehingga dikategorkan sebagai air lunak yang tidak membutuhkan pengolahan bila akan dikonsumsi sebagai air minum. Untuk kepentingan industri yang menggunakan ketel uap, air yang digunakan harus terbebas dari kesadahan. Hal ini dikarenakan kalsium dan magnesium karbonat cenderung mengendap pada permukaan pipa dan permukaan penukar panas.

Kesadahan air adalah kandungan mineralmineral tertentu di dalam air, umumnya ion kalsium $(\mathrm{Ca})$ dan magnesium $(\mathrm{Mg})$ dalam bentuk garam karbonat. Air sadah atau air keras memiliki kadar mineral yang tinggi, sedangkan air lunak adalah air dengan kadar mineral yang rendah. Selain ion kalsium dan magnesium, penyebab kesadahan juga bisa merupakan ion logam lain maupun garamgaram bikarbonat dan sulfat.
Air yang bersifat sadah dapat menyebabkan cardiovascular (penyumbatan darah jantung) dan urolithiasis (batu ginjal), menyebabkan pengerakan pada peralatan logam untuk memasak sehingga penggunaan energi menjadi boros, penyumbatan pada pipa logam ${ }^{(34)}$.

Masalah air sadah banyak ditemukan di daerah yang mengandung komposisi kapur atau pada daerah batugamping. Kondisi tanah yang mengandung batuan gamping menyebabkan tingkat kesadahan airtanahnya relatif tinggi (keras). Air tanah di daerah batuan gamping mengandung ionion $\mathrm{Ca}^{2+}$ dan $\mathrm{Mg}^{2+}$ dalam jumlah yang cukup besar $^{(35)}$. Ditinjau dari kondisi geologi, batuan yang terdapat di kabupaten Serang dan bagian hulu tidak didapatkan batugamping yang biasanya mempunyai pengaruh besar terhadap kesadahan airnya. Batuan tipe volkanik yang banyak didapatkan di Kaupaten serang dan bagian hulunya, tidak banyak mempengaruhi terhadap kesadahan airnya, baik airtanah mapun air permukaan.

Daerah yang berdekatan dengan kawasan industri, pencemaran airtanah yang berasal dari industri tidak sampai mempengaruhi terhadap kesadahan airtanah dan air permukaan yang berada di sekitarnya. Demikian juga pengaruh pencemaran limbah domestik juga tidak sampai mempengaruhi kesadahan airtanah maupun air permukaan.

Mengingat sumber kesadahan yang berupa material tanah (batuan) dari daerah hulu sungai, pencemaran limbah industri maupun domestik yang relatif sangat kecil, maka banjir yang terjadi pada lokasi penelitian tidak akan banyak terjadi peningkatan kesadahan baik di air permukaan maupun airtanah penduduk. 


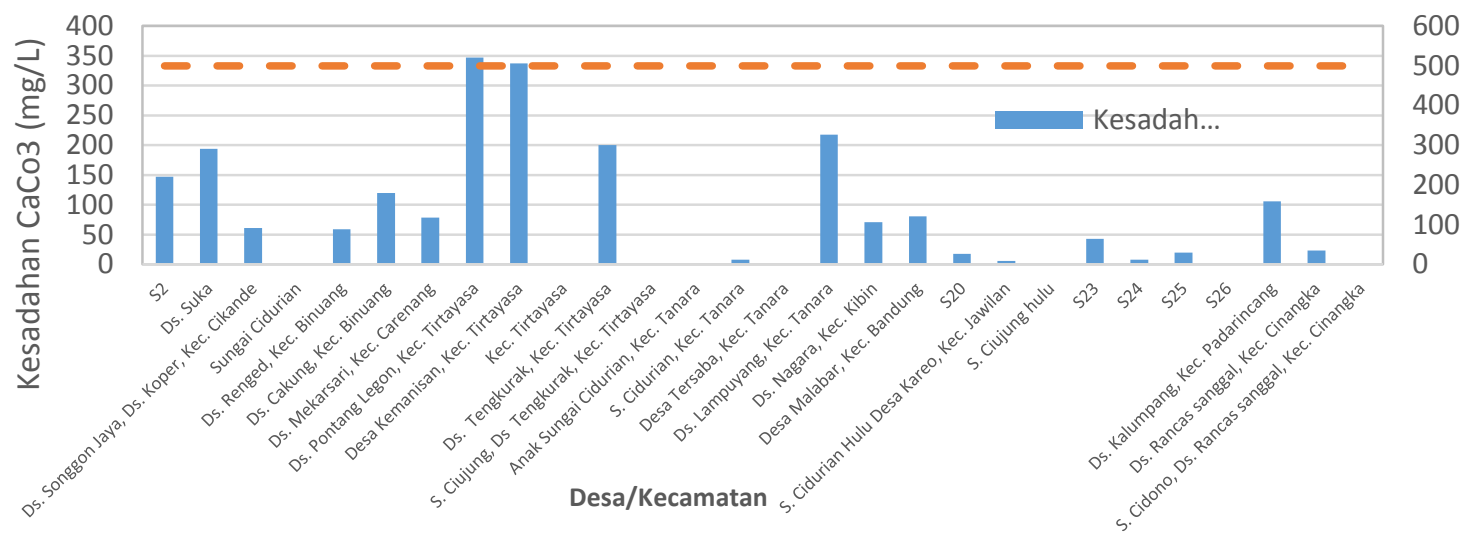

Gambar 12. Kesadahan air pada sampel air sumur dan sungai

\section{KESIMPULAN}

Dari hasil pembahasan di atas, maka bisa disimpulkan sebagai berikut:

a. Hasil analisis parameter kekeruhan dan zat padat terlarut pada musim kemarau 2013 dan musim hujan 2016 menunjukkan terjadinya peningkatan kekeruhan dari hulu ke hilir Sungai Ciujung dan Sungai Cidurian.

b. Hasil pemantauan kualitas air pada parameter kekeruhan di Sungai Cidanau dan beberapa sungai kecil di DAS Cidanau menunjukkan bahwa kekeruhan relatif rendah dibandingkan kekeruhan yang ada di Sungai Cidurian dan Sungai Ciujung, akibat tingkat erosi yang terjadi di DAS Cidanau lebih rendah dibandingkan dengan Sungai Ciujung dan Sungai Cidurian.

c. Tingginya nilai $\mathrm{NH}_{3}-\mathrm{N}$ di beberapa sumur penduduk kemungkinan besar disebabkan oleh limpasan air permukaan yang membawa limbah organik masuk ke dalam sumur penduduk terutama yang tidak terlindungi terutama pada saat banjir. Nilai $\mathrm{NH}_{3}-\mathrm{N}$ yang tinggi di Sungai Cidanau, Sungai Ciujung dan Sungai Cidurian kemungkinan besar karena adanya kontribusi penggunaan pupuk organik dan anorganik di lahan pertanian dan perkebunan yang dapat terbawa aliran permukaan pada saat banjir ke dalam sumur penduduk yang tidak terlindungi.

d. Kandungan Fe dan $\mathrm{Mn}$ dari semua sampel air sumur maupun air sungai secara umum melampaui baku mutu Golongan I, hal ini berkaitan dengan kondisi geologi di Kabupaten Serang yang banyak mengandung Besi dan Mangan pada air tanahnya. e. Berdasarkan hasil pengukuran kesadahan pada keseluruhan sampel air dikategorkan sebagai air lunak, akibat minimnya sumber terjadinya kesadahan yang berasal dari batuan di sekitar dan daerah hulu, pencemaran industri maupun domestik.

f. Secara umum air tanah pada daerah banjir di lokasi penelitian menunjukkan kualitas yang masih layak untuk dikonsumsi oleh masyarakat, kandungan $\mathrm{Fe}$ dan $\mathrm{Mn}$ yang tinggi perlu dilakukan proses aerasi dan pengendapan terlebih dahulu sebelum dikonsumsi.

g. Parameter $\mathrm{NH}_{3}-\mathrm{N}$ tidak dipersyaratkan dalam persyaratan baku mutu kualitas air minum terbaru menurut Permenkes No 492/Menkes/Per/IV/2010. Sedangkan pada KepMenKes No. 907/MENKES/SK/VII/2002 tidak ditetapkan baku mutu amonia. Baku mutu amonia ditetapkan sebesar $0,5 \mathrm{mg} / \mathrm{L}$ dalam bentuk $\mathrm{NH}_{3}$ bebas atau setara dengan $\mathrm{NH}_{3}-\mathrm{N}=0,0411 \mathrm{mg} / \mathrm{L}$ pada PP No. 82 Tahun 2001 untuk kelas mutu air golongan 1. Sementara untuk menghindari tingginya nilai $\mathrm{NH}_{3}-\mathrm{N}$ yang melampaui baku mutu pada beberapa sumur penduduk perlu dilindungi dengan bangunan pelindung sumur untuk mencegah air permukaan termasuk air banjir masuk ke dalam airtanah.

\section{PERSANTUNAN}

Ucapan terima kasih kami sampaikan kepada Balitbang Provinsi Banten, khususnya kepada Dr. H. Ajak Moeslim, M.Pd., Ir. H. Doddy Setia Graha, M.Si, Hj. Atin Martini, SH. MA. dan Anita Widiastuti, SSTP., M.Si. Ucapan terima kasih juga kami sampaikan kepada Ir. Eko Widi Santoso MS. sebagai Direktur PTRRB-BPPT dan Wiwiek Dwi Susanti ST., MT. Penelitian ini merupakan bagian dari kerjasama penelitian antara 
PTRRB- BPPT dan Balitbang Provinsi

Banten.

\section{DAFTAR PUSTAKA}

1. Hrdinka, T., Novicky, O., Hanslik, E., \& Rieder, M. (2012). Possible impacts of floods and droughts on water quality. Journal of Hydro-environment Research, 6(2), 145-150.

2. Sun, R., An. D., Lu, Wei., Yun, S., Wang, L., Zhang, C., Zhang, P., Qi, H., \& Wang, Q. (2012). Impacts of a flash flood on drinking water quality: case study of areas most affected by the 2012 Beijing flood. Heliyon, Article no. e00071.

3. Ching, Y.C., Lee, Y.H., Toriman, M.E., \& Abdullah, M., Baharudin. (2015). Effect of the big flood events on the water quality of the Muar River, Malaysia. Sustainable Water Resources Management, 1(2), 97110

4. Heriyanto, A. (2018). Studi pengaruh perubahan tata guna lahan DAS Ciujung bagian hulu terhadap debit di Sungai Ciujung. Masters thesis, Institut Teknologi Sepuluh Nopember.

5. Sulaeman, D., Hidayat, Y., Rachman, L.M., \& Tarigan, S.D. (2014). Kajian dampak perubahan penggunaan lahan terhadap debit aliran DAS Ciujung. Infrastruktur, 4 (2),. $78-85$.

6. Kusumo, P., \& Nursari, E. (2016). Zonasi tingkat kerawanan banjir dengan sistem informasi geografis pada DAS Cidurian Kab. Serang, Banten. Jurnal String, 1(1), 29-38.

7. Hindriani, H. (2013). Kajian peningkatan kualitas air Sungai Ciujung berdasarkan parameter senyawa AOX (Adsorbable Organic Halides) dengan model WASP (Water Quality Analysis Simulation Program) dan model dinamis. Sekolah Pascasarjana, IPB.

8. Hindriani, H., Sapei A., \& Suprihatin, Machfud. (2013). Pengendalian pencemaran Sungai Ciujung berdasarkan analisis daya tampung beban pencemar. Jurnal Sumber Daya Air, 9(2), 169-184.

9. Andini, A.P. (2017). Strategi pengelolaan kualitas air Sungai Ciujung berdasarkan daya tampung beban pencemaran dengan metode Qual2kw. Program Magister IImu Lingkungan UNDIP.

10.Kartika, W. I. (2012). Analisis beban pencemaran dan kapasitas asimilasi Sungai Cidurian, Provinsi Banten. Sekolah Pasca Sarjana, IPB.

11.Prihartanto. (2017). Water turbidity fluctuation pattern in the potential flood area of the Ciujung River in Kragilan District, Serang Regency. Jurnal Alami, 1(1). 17-20.
12.BPS Kabupaten Serang. (2014). Kabupaten Serang dalam angka.

13.BPBD Kabupaten Serang. (2016). Data banjir Kabupaten Serang tahun 2012, 2013, 2014, dan 2015.

14.Prasetyo, M. (2007), Perencanaan Bendungan Cibanten untuk penyediaan air baku dan irigasi di Kabupaten Serang. Tugas Akhir Sarjana, Program Studi Teknik Sipil ITB, Fakultas Teknik Sipil dan Lingkungan, Institut Teknologi Bandung.

15.Prihartanto, Naryanto, H.S., \& Ganesha, D. (2017). Distribusi spasial airtanah dangkal di DAS Ciujung dan Cidurian, Kabupaten Serang, Provinsi Banten. JTL, 18(2), 216223.

16.Nazir, M. (1983). Metode penelitian. Ghalia Indonesia. Bogor.

17.Akhirianto, N.A., \& Naryanto, H.S. (2016). Kajian kapasitas dan persepsi masyarakat Pangalengan terhadap bencana tanah longsor. JRKI, 2(2).

18.Sugiyono. (2010). Metode penelitian (Pendekatan kuantitatif, kualitatif dan $R \& D)$. Alfabetha, Bandung.

19.Sekretariat Negara RI. (2001). Peraturan Pemerintah Republik Indonesia Nomor 82 Tahun 2001 tentang pengelolaan kualitas air dan pengendalian pencemaran air.

20.Badan Standardisasi Nasional. (2009). SNI 6989 Air dan air limbah.

21.Pemerintah Kabupaten Serang. (2008). Rencana tata ruang wilayah Kabupaten Serang 2009-2029.

22.Naryanto, H.S., Prihartanto, Soewandita, H., Prawiradisastra, F., Zahro, Q., Marwanta, B., Wisyanto, Raharjo, A.P. (2017). Master plan dan action plan kebencanaan Kabupaten Serang. BPBD Kabupaten Serang - BPPT, Laporan.

23. American Public Health Association (APHA), the American Water Works Association (AWWA), and the Water Environment Federation (WEF). (1999). Standart method for examination of water dan wastewater. 22nd edition.

24. Hindriani, H. (2013). Kajian peningkatan kualitas air Sungai Ciujung berdasarkan parameter senyawa AOX (adsorbable organic halides) dengan model WASP (water quality analysis program) dan model dinamis. Thesis S2, Sekolah Pasca Sarjana IPB.

25.Weiner, E. R. (2012). Applications of environmental aquatic chemistry: A Practical Guide. Third Edition, CRC Press.

26.Naryanto, H.S., Prihartanto, Susanti, W.D., Widiastuti, A., \& Ganesha, D. (2016). Kajian pengendalian dan penanggulangan bencana banjir di Kabupaten Serang. 
Balitbangda Provinsi Banten-BPPT, Laporan.

27.Sujudi, A. (2002). Keputusan Menteri Kesehatan Republik Indonesia Nomor : 907/MENKES/SK/VII/2002 tanggal 29 Juli 2002, tentang syarat-syarat dan pengawasan kualitas air minum.

28. Ridhosari, B., Roosmini, D. (2011). Evaluasi kuaitas air tanah dari sumur gali akibat kegiatan domestik di Kampung Daraulin-Desa Nanjung, Jurnal Teknik Lingkungan ITB, Vol. 17, No. $1 \mathrm{Hal}$; 47-58.

29. Lubis, A., Inswiasri, Tugaswati, T. (1987). Amonium dalam sumur penduduk. Bul. Penglit Kesehatan (15)1.

30. Amaliah, I. (2018). Analisis hubungan faktor sanitasi sumur gali terhadap index fecal coliform di Desa Sentul Kecamatan Kragilan Kabupaten Serang. Skripsi, Peminatan Kesehatan Lingkungan, Prodi Kesehatan Masyarakat, FKIK UIN Syarif Hidayatullah.

31. Putri, S.U.D. (2014). Analisis kualitas Sungai Ciujung menggunakan model WASP (water quality simulation program). Skripsi S1, Teknik Sipil dan Lingkungan, Fak. Teknologi Pertanian IPB.
32. Kelompok Teknologi Pengelolaan Air Bersih dan Limbah Cair - PTL, BPPT. (2018, Monday, December 15, 2018). Pembuatan filter untuk menghilangkan zat besi dan mangan di dalam air, Retrieved from

http://www.kelair.bppt.go.id/Sitpa/Artikel/Filt er/filter.html.

33. Sedyaningsih, E.R. (2010). Peraturan Menteri Kesehatan Kementerian Kesehatan No. 492/MENKES/PER/IV/2010, tentang persyaratan kualitas air minum.

34. Wulandari, D. D. (2017). Analisa kesadahan total dan kadar klorida air di Kecamatan Tanggulangin, Sidoarjo. MTPH Journal, 1(1), 14-19.

35. Setyaningsih, N. (2014). Analisis kesadahan air tanah di Kecamatan Toroh Kabupaten Grobogan Propinsi Jawa Tengah. Publikasi Karya Ilmiah Fakultas Geografi Universitas Muhammadiyah, Surakarta. 